\title{
Microfinance Managerial Capability Strategic Development of Female Street Vendors in Surabaya and Sidoarjo
}

\author{
Arasy Alimudin (arasy.alimudin@ narotama.ac.id); Reswanda (reswanda@narotama.ac.id) \\ Department of Management, Faculty of Business and Management \\ Narotama University of Surabaya, Indonesia
}

\begin{abstract}
Most research on female entrepreneurs revealed that poor in capital capacity and managerial capability become the most problems for them to move ahead. These female street vendors poor of capability in microfinance management also become other crucial issue to be solved besides some other key issues on business planning, administrating, creating source of business financing, to survive in such competitive world. This study examines the effectiveness of financial management capability of female street vendors in strengthening their business capital and reducing the bankruptcy risk and poverty. This research conducted a survey and examined indepth problem to get the formulation of the problems of female street vendors in facing and solving problems as alternative strategies to empower them. The Data techniques analysis used in this study is descriptive analysis techniques which were used to examine the specific characteristics and profile formulation of female street vendors in the area. Descriptive analysis techniques supported by statistical analysis techniques using logistic regression to describe the methods of business financial management female street vendors in Surabaya and Sidoarjo. The result of this research shows that the main problems faced by female street vendors in Surabaya and Sidoarjo is lack of capability in making bargaining power in competitive rigidity to larger range similar business and lack of capability in financial management strategic development. The most effective method in strengthening the female street vendors is by making similar range on their business to be one specific group that is accommodated in association supported by the government.
\end{abstract}

Keywords: Microfinance management, female street vendors, strategic development

\section{Introduction}

The successful of development is largely determined by the extent to which development is able to increase the economic growth, increase per capita income and reduce the unemployment through the employment creation, all of them which are aimed at reducing the number of people living below the poverty line. In September 2016, the number of poor people (people with per capita expenditure per month below the poverty line) in Indonesia reached 
27.76 million people (10.70 percent). The average monthly wage of the laborers/ employees in February 2017 was 2.70 million rupiahs, the highest wage was in the electricity, gas and water sector which got 4.43 million rupiahs while the lowest one was in the agriculture sector which was 1.75 million rupiahs. If compared to the sex, the average monthly salary/wage of the laborers and employees, the male employees' salary is higher than the women that is 2.95 million rupiah and 2.27 million rupiah. This fact shows that the issue of gender is still a difference in the level of salary, the male's salary is higher that the women's whereas the number of female workers is higher than that of men (Statistik, 2016). One way to reduce the poverty line while maintaining the gender quality aspect is by empowering the micro business especially the informal sector from 124,54 million people working as much as $58.35 \%$ work in informal sector. Based on the results of the business registration of Economic Census 2016 (SE2016), the number of non-agricultural business reached 26.7 million business, it is increased for about $17.6 \%$ if compared to the business result of Economic Census 2006 which recorded 22.7 million business. It is recorded as many as 7.8 million businesses that occupy a special building for business premises from 26.7 million businesses of SE2016 result. Thus, as many as 18.9 million businesses do not occupy the business specific buildings, such as traveling traders, businesses in residential business, street businesses, and so forth. The number of micro business in eastern Java in 2015 is about 771,185 businesses with the employment is 1,518,302 (Statistik, 2016).

There are various efforts that have been made by the government and the private sector (Lembaga Donor) to develop the Small and Medium Enterprises (UKM), such as the development of adoptive father-child adoption pattern between UKM and the large scale business, the cooperative development and partnership program, and the program of one village one billion. In the field of credit, the government has implemented many programs such as Small Business Credit (KUK), Business Feasibility Loan (KKU), People's Business Loans, Ultra Micro Credit and others, with the aim to develop UKM directly and indirectly that will impact on the poverty reducing. The adoptive father-son program is less successful because it is not based on the mutually beneficial business principles but rather the social. The failure of effort done by the governments and other donors is due to the government's haste in providing the support and wisdom. Where the haste in applying support to the small people economy has led to the wastage of the national resources, due to the ineffectiveness and efficiency of the small business development programs but even impressed to have the undermined social capital, social accountability and the community responsiveness. This can lead to the loss of public awareness in the development and over-reliance of the public on the government, thus disrupting the empowerment programs of other donor agencies.

In order to support the target achievement optimization of small business development program, it is required a mature analysis, not only from the economic point of view but also viewed from the socio-cultural and socioeconomic aspects of the society that will affect both directly and indirectly development of small scale enterprises.

The number of UMKM managed by women is more than the number of UMKM managed by men (Sri Lestari Harsosumarto, 2017). The trade sector is chosen as the economic 
activity according to the East Java BPS Data, the rate growth of the trade sector in the employment increased by $6.3 \%$ annually, the number of residents in East Java who were selfemployed reached 3,027,840 (Jatim, 2014). While the number of SMEs in Surabaya, which is engaged in the trade sector as much as $65 \%$ and In Sidoarjo as much as $56 \%$ (DISKOP UKM JATIM, 2017).

The existence of women is also very significant in the development especially in supporting the increase of income and family welfare to reduce poverty, but many studies shows that the problem of capital lack and management capability is a key issue that must be studied before determining the business development program of female entrepreneurs(Agusni, 2015; Darwin, 1998; Jati, 2012; Sumantri, B., Fariyanti, A., \& Winandi, 2013). Besides that, the motivation of female small traders in entrepreneurship shows that the greatest percentage of their motivation is the fulfillment of the economic needs, but especially for Semarang area, the higher the education of respondents the less the percentage that has the motivation to meet the need of their economy (Endang S, 1999). The guidance and assistance needed by the women of small traders mostly requires the capital assistance, with the smallest requirements (Wijaya, 1999). The capital condition of female street vendors is also often ups and downs due to the debt and the lack of financial management knowledge which is vulnerable to get the exploitation by the irresponsible parties (Arifin, 2004). The business of street vendors in culinary field also shows an encouraging impact where the street vendors are able to reduce the unemployment rate in Surabaya, but the level of coaching in business management is still very minimal (Satrya, 2009; Suryani, H., \& Faizah, 2015; Wispandono, 2011). The factors which influence the income level of the street vendors in Surabaya include the managerial capability, economic aspects, product quality and service quality, and which have a great influence on the income of street vendors are the managerial and the economic aspects (Handayani, C. M. S., \& Wibowo, 2016). Similarly, Sidoarjo street vendors' ability to innovate and overcome the faced various business problems such as the problem of capital and the level of competition affect the sustainability of the business street vendors in Sidoarjo (Prasetya, M. A., \& Fauziah, 2017; Syaifudin, 2017).

From some previous reviews above, it can be concluded that the female small traders want a practical, easy to understand and easy to do either in managing their business or in getting the business capital. Therefore, the guidance given to the female street vendors should be a method of assistance that accustoms the women entrepreneurs to conduct the business management with a simple approach and acceptable by the female street vendors. Besides that, to build the motivation in the business management especially in finance, it is necessary to form a group of female street vendors so that they will be able to conduct the interaction and cooperation that will support their effort of independence and professionalism.

This research is a survey and action research which examines an in-depth problem to get the formulation of the female street vendors problem and then look for an overview of problem solving described in alternative strategies. Then implemented in empowerment activities. The data analysis techniques used in this study is, first a descriptive analysis which used to examine the characteristics of female street vendors and formulate the female street vendors in the 
location of the study. In this research, the position of the researcher who is considered as an outsider acts as a facilitator. The obtained information then analyzed together and applied directly by the community. The expected outcomes of participatory research activities are the behavioral changes so that the long-term institutional and sustainable community actions are formed (Mikkelsen, 2011). The population of this study is female street vendors in the area of Surabaya and Sidoarjo regency. The sample was chosen by using the purposive random sampling technique. The number of samples is determined of 100 respondents, so as a whole amounted to 200 people.

The descriptive analytical techniques supported by the statistical analysis techniques regression logistic is also used to describe the review of the method of business financial management, the female small street vendors in Surabaya and Sidoarjo (Dahlan, 2011; Wahab, 2014).

\section{Discussion}

The general respondents in Sidoarjo regency, $43.6 \%$ were over 46 years old, $40 \%$ were aged between $36-45$ years, $15.5 \%$ were 31 to 35 years old, and only (0.9) were aged between 17-20 years. The respondents in Surabaya city, $34 \%$ were over 46 years old and most or $41.7 \%$ were younger (aged $41-45$ years) and about 24.3\% were aged between 31-35 years.

In terms of education, generally the respondents in both regions (Surabaya and Sidoarjo) did not show the significant differences, as many as $13.5 \%$ and $25 \%$ did not complete the primary school, $56.5 \%$ and $50.0 \%$ in Surabaya and Sidoarjo were graduated from primary school and the rest $30 \%$ and $20 \%$ respondents were educated above it. The gross income of the respondents in Surabaya is bigger than in Sidoarjo, $46.1 \%$ have the income for above Rp. $900.000 /$ month, while in Sidoarjo with the same income only as much as $14.5 \%$. most $57.3 \%$ of the resondents in Sidoarjo have the income between Rp. 300.000 - Rp. 500.000, while Surabaya with the same revenue between Rp. 300.000 - Rp. 500.000 as much as $18.3 \%$.

\section{The Condition of Female Small Street Vendors}

Table 1. Difficulties faced by Female Small Street Vendors

\begin{tabular}{|ll|r|r|r|r|}
\hline & Frequency & Percent & Valid Percent & $\begin{array}{c}\text { Cumulative } \\
\text { Percent }\end{array}$ \\
\hline Valid & Marketing Difficulties & 10 & 5.0 & 5.0 & 5.0 \\
& Capital Difficulties & 167 & 83.5 & 83.5 & 88.5 \\
Raw Material & 11 & 5.5 & 5.5 & 94.0 \\
Difficulties & 12 & 6.0 & & \\
Competitiveness & 200 & 100.0 & 100.0 & 100.0 \\
Total & & & \\
\hline
\end{tabular}


From table 1, it can be explained that during this main difficulty which faced by the female street vendors in running their business is the capital problem as much as $83.5 \%$, therefore the capital support is needed to improve their business and their competitiveness.

Table 2. How the female street vendors overcome the capital difficulties

\begin{tabular}{|l|r|r|r|r|}
\hline & Frequency & Percent & Valid Percent & \multicolumn{1}{c|}{$\begin{array}{c}\text { Cumulative } \\
\text { Percent }\end{array}$} \\
\hline Valid the & 4 & 2.0 & 2.0 & 2.0 \\
$\begin{array}{l}\text { Ask government help } \\
\text { Ask help from } \\
\text { friend }\end{array}$ & 41 & 20.5 & 20.5 & 22.5 \\
Keep Silent & 155 & 77.5 & 77.5 & 100.0 \\
Total & 200 & 100.0 & 100.0 & \\
\hline
\end{tabular}

From table 2, it can be seen that the way of the female street vendors to overcome the capital difficulties is because the limited information and access to the capital source in the face of capital difficulties are mostly resigned or silent but there are some who ask for help from friends.

Table 3. The Female Street Vendor's opinion on their capital

\begin{tabular}{|ll|r|r|r|r|}
\hline & Frequency & Percent & Valid Percent & $\begin{array}{c}\text { Cumulative } \\
\text { Percent }\end{array}$ \\
\hline Valid & Enough & 6 & 3.0 & 3.0 & 3.0 \\
& Less & 49 & 24.5 & 24.5 & 27.5 \\
Very Less & 145 & 72.5 & 72.5 & 100.0 \\
Total & 200 & 100.0 & 100.0 & \\
\hline
\end{tabular}

Based on table 3, it can be explained that the opinion of Female street vendors to their own capital is less $24.5 \%$ and very less $72.5 \%$

Table 4. The way that female street vendors overcome the lack of their capital

\begin{tabular}{|c|c|c|c|c|c|}
\hline & & Frequency & Percent & Valid Percent & $\begin{array}{l}\text { Cumulative } \\
\text { Percent }\end{array}$ \\
\hline \multirow[t]{5}{*}{ Valid } & Borrow BPR & 4 & 2.0 & 2.0 & 2.0 \\
\hline & Borrow BMT & 36 & 18.0 & 18.0 & 20.0 \\
\hline & $\begin{array}{l}\text { Borrow the } \\
\text { moneylender }\end{array}$ & 36 & 18.0 & 18.0 & 38.0 \\
\hline & Borrow Family & 124 & 62.0 & 62.0 & \multirow[t]{2}{*}{100.0} \\
\hline & Total & 200 & 100.0 & 100.0 & \\
\hline
\end{tabular}

Based on table 4, it can be explained that the capital shortages have been overcome largely by lending to families $62 \%$ and there are $36 \%$ who cope with borrowing the moneylenders and BMT. 
Table 5. The reason of female street vendors to overcome the lack of their capital in such way

\begin{tabular}{|c|c|c|c|c|c|}
\hline & & Frequency & Percent & Valid Percent & $\begin{array}{c}\text { Cumulative } \\
\text { Percent }\end{array}$ \\
\hline \multirow[t]{4}{*}{ Valid } & Low Interest & 172 & 86.0 & 86.0 & 86.0 \\
\hline & $\begin{array}{l}\text { Without } \\
\text { Guarantee }\end{array}$ & 12 & 6.0 & 6.0 & 92.0 \\
\hline & Other & 16 & 8.0 & 8.0 & 100.0 \\
\hline & Total & 200 & 100.0 & 100.0 & \\
\hline
\end{tabular}

Based on table 5, it can be explained that the reason to overcome the lack of their capital in such ways is looking for the low interest and without guarantee.

Table 6. What do the female street vendors if given the capital assistance

\begin{tabular}{|c|c|c|c|c|c|}
\hline & & Frequency & Percent & Valid Percent & $\begin{array}{c}\text { Cumulative } \\
\text { Percent }\end{array}$ \\
\hline \multirow[t]{5}{*}{ Valid } & $\begin{array}{l}\text { Repairing the } \\
\text { business place }\end{array}$ & 22 & 11.0 & 11.0 & 11.0 \\
\hline & $\begin{array}{l}\text { Adding the } \\
\text { goods }\end{array}$ & 160 & 80.0 & 80.0 & 91.0 \\
\hline & Promotion & 15 & 7.5 & 7.5 & 98.5 \\
\hline & Other & 3 & 1.5 & 1.5 & 100.0 \\
\hline & Total & 200 & 100.0 & 100.0 & \\
\hline
\end{tabular}

Table 6 shows that the most women street vendors will increase their merchandise if they are given $80 \%$ of their business capital.

While the compensation that will be given by the women street vendors when given the capital mostly only returns in accordance with their loan $84 \%$, partially refunded in $15 \%$ terms and only $1 \%$ are willing to return with profit sharing.

Table 7. The desire to develop the female street vendors

\begin{tabular}{|rl|r|r|r|r|}
\hline & Frequency & Percent & Valid Percent & $\begin{array}{c}\text { Cumulative } \\
\text { Percent }\end{array}$ \\
\hline Valid & Yes & 91 & 45.5 & 45.5 & 45.5 \\
& No & 109 & 54.5 & 54.5 & 100.0 \\
& Total & 200 & 100.0 & 100.0 & \\
\hline
\end{tabular}

Table 7 shows that $54.5 \%$ of the female street vendor respondents say that they do not want to expand their business, and only $45.5 \%$ want to expand their business. This is due to the high level of competition that decrease the desire to develop the business of female street vendors and the lack of the government support for the sustainability of their business. 
The underlying of female street vendors to expand their business largely assume that their efforts can be inherited as much as $56.5 \%$ and as much as 36.55 is because they like their business. While the cause of the female street vendors who do not want to develop their business, as much as $64 \%$ is because it considers the useless considering to the high level of competition and low consumer interest, this also causes $26 \%$ feel like looking for another job and $10 \%$ is because of tired. Most of the female street vendors think that their business is unsuccessful or stagnant, only $14.5 \%$ of them feel that their business is growing and $0.5 \%$ say that they have succeed. For the female street vendors who are successful in developing their business, they consider to be able to restore the adequate capital and the infrastructure, meanwhile the female street vendors who fail to feel the consequences is due to the situation, lack of available infrastructure and lack of connection. Although the business is less successful, most of the female street vendors do not want to switch to another business as much as $72 \%$, because they think it will be troublesome and have to start all over again. Whereas if the street vendors turn to other business, as much as $48 \%$ they tempt to resign anything and trade the other type $40 \%$. And the desire to switch to the other entrepreneurs is mostly due to the desire of female street vendors in trying to their area of expertise. Although psychologically the female street vendors are under severe pressure in developing their business, but their interest is still big enough to keep trying, where $49.5 \%$ are still continuing their business and $47.5 \%$ say that they stop immediately.

The female street vendors admitted that their business capital is the result of their own effort. They are very hopeful of a touch of a business capital that is not too binding such as banking. In this context, the banking/ credit institutions have not been consistent in the realization of the loan fund proposed by the female street vendors in Sidoarjo. It is based on the recognition of the respondents who claimed that their business capital is the result borrowed from their family.

The disbursement of loan funds to the female street vendors by the bank is more based on the consideration of female asset vendors who have applied for a large loan. This means that for the female street vendors which have the small capital, it is quite difficult to obtain the loan funds from banks/ other credit institutions. Therefore, the percentage of female street vendors who often associated with the bank in order to finance their business activities is very small. In this case, the support of the local financial institutions in the form of providing the soft loans to the women street vendors is Sidoarjo is still very less.

The large business capital that has been used, mostly 46 people $(41.8 \%)$ of the women street vendors in Sidoarjo is less than Rp. 5 million, only 1 respondent $(0.9 \%)$ whose capital is above Rp. 10 million. Based on the result of the survey, the female street vendors in Sidoarjo may still be left behind if compared to the female street vendors in Surabaya, both in terms of capital marketing and business management.

The female street vendors are still far from the touch of professional management to develop their business. This is not easy to do considering the capacity of female street vendors to be willing and aware to the importance of the effective and efficient business management such 
as the current situation is still in "doubt". Therefore, with the various limitation, they still do not move from their status as the entrepreneurs of the traditional traders.

During this time, for about $89.5 \%$ of the female street vendors buy their merchandise in cash, thus causing the need for the business sustainability capital becomes very big influence. Similarly, in determining the selling price based on the market price of $75 \%$, this condition resulted in the amount of the profit which sometimes less well controlled. Because if the cost increment on the price of taking will cause the harm to the female street vendors.

Most of the female street vendors in binding their customers use the means by giving the ease payment of $72 \%, 14 \%$ tie by giving cheap price and $13 \%$ with the scale exaggerated. Giving the ease payment because the average buyer is still partially bought by borrowing awaiting the salary or goods behaviors. This condition causes the female street vendors have a low level in savings and investments, so that the existence of the additional capital becomes very important.

The above phenomena are triggered by the external conditions of female street vendors who consider the issue of the expensive prices and the uncomfortable place condition according to the street vendors are those that make the buyer disappointed. So the female street vendors try to fix the stores and places of their business, but this situation causes the cost of high overhead and reduce their profit. The problem of the capital weakness and the ability of management in facing the competitor is a key problem which become the main obstacle of the women entrepreneurs' business development program. Basically, the result of in-depth interviews and observations reveal the problem of the weak capability of managing the female street vendors includes several key issues, they are (1) the weakness in business planning especially in anticipating the changes in tastes and needs of the customers and anticipate the changes in purchase price of raw materials or wholesale goods. (2) The weakness in reporting and managing the money. (3) The weakness in the creation of overcoming several problems such as capital problems, costs and wholesale goods, marketing, competitiveness and so forth. (4) The weakness in accepting the information and learning it from the competitor. (5) The lack of motivation and the entrepreneurship vision. These conditions were seen from the statement of the female street vendors about various factors which cause the female street vendors do not want to develop their business, for about $64 \%$ of Female street Vendor say that it is nonsense because of the high level of competition and the low level of the consumers needed, for about $26 \%$ feel of looking for the other type of business and $10 \%$ is because of tired.

The high level of competition especially the developing of supermarkets and the growing of the moneylenders cause the female street vendors cannot be able to strengthen their quality from both the capital side and the cost side. Therefore, the entrepreneurship oriented is needed to develop the business motivation of the female street Vendors(Alimudin, 2013; Zhou, Kevin Zheng, Chi Kin Yim, 2005). 
Table 8. The logistic regression analysis of the debt amount (X1), capital amount (X2), receivables amount $(\mathrm{X} 3)$ to the interest of the female street vendors.

\section{Variables in the Equation}

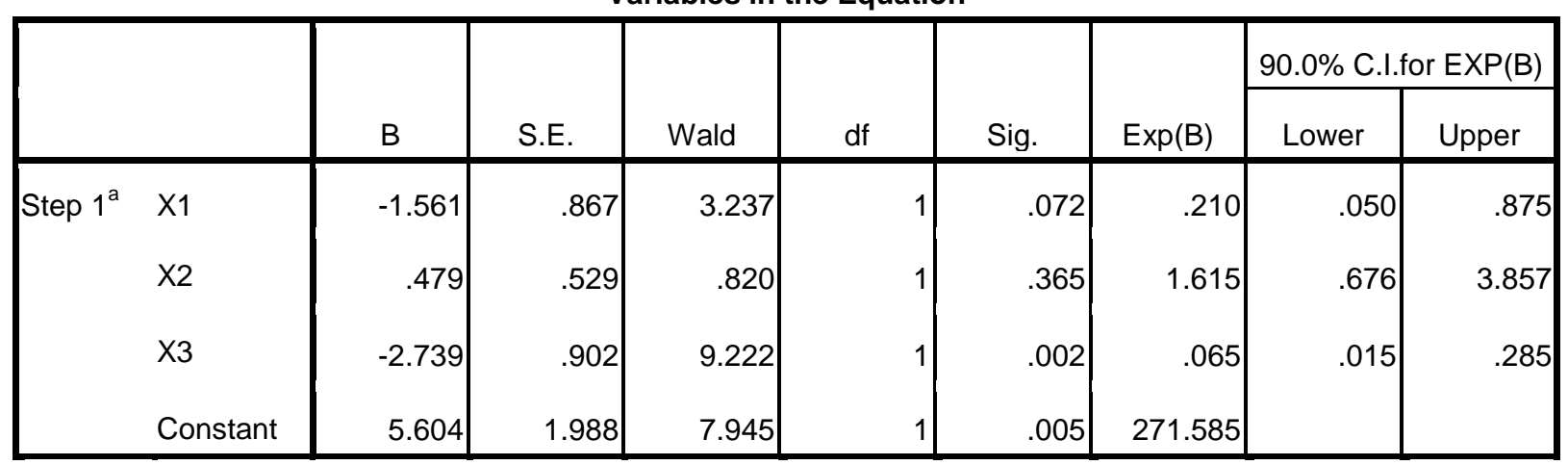

a. Variable(s) entered on step 1: X1, X2, X3.

It can be explained from the table 8 about the significant level of $90 \%$ which make the variable impact to the interest of the female street vendor is the amount of receivables (0.002) with the negative symbol explained the reduced amount of receivables will increase the profits of female street vendors, and the debt amount (0.072) which the negative symbol shows that the reducing the amount of debt will increase the profits of female street vendors. While the amount of debt has no significant effect with a positive sign which means because of the average purchase made by female street vendors is by way of cash.

The researcher tries to offer the concept of action in the form of congressional steps, the first is goal setting by empowering yourself or together in both independently economically and independently organizationally. The second is the principle setting of overcoming the problems or challenges with their own abilities. The third is the development determination of ability or expertise which the female street vendor must continuously make the innovation or the business breakthrough, ability to overcome the capital, managerial capabilities include the procurement of raw materials/ merchandise by more traders by providing /buying themselves to the suppliers despite the suppliers who went to the merchant. For that, it is necessary to be able to buy with credit through the cooperation among the female street vendors. Then for the payment system made by the consumers are all almost in cash, this is in line with the result of logistic regression analysis which has a great influence on the income of street traders is the number of debt amount (X1) with the negative sign and total receivables amount (x3) with negative sign. The fourth is initial determination of the initial steps which were set up by the initial team to initiate the initial meeting to formulate the activities. The fifth, the stipulation that local government support should be clear in the priority, whether to play a role in the development of access, market information or capital, here the role of government is needed as a mediation between the female street vendors with the aid providers or capital loans for micro enterprises(Alimudin \& Sasono, 2015). This is in line with what the ILO has said that Indonesia needs to be more focused on the factors that drive spending inequality and support the functioning of the labor market, in order to create the more equitable access to labor the market information and the employment 
opportunities. In particular, the effort to reach out to the businesses and the workers in the informal sector through the employers and workers organizations may be an effective strategy to promote the transition to formality(Ilo, 2015).

\section{Conclusion}

The main problem faced by the female street vendors in Surabaya in Sidoarjo is their ability and their bargaining power in the face of competition with the power of the large investors. The low ability of the female street vendors in managing the finances, especially in the management of savings and investments in business profits, has become an emphasis in the development strategy of microfinance management of street vendors in Surabaya and Sidoarjo, and the most effective method of the business finance management is the formation of similar business group which are accommodated in an association by the government.

\section{Bibliography}

Agusni, S. (2015). Koperasi Wanita dengan Perbankan dalam Penyaluran Kredit Mikro Bagi Usaha Perempuan. INFOKOP, 15(2). Retrieved from http://www.smecda.com/jurnal/index.php/infokop/article/view/53

Alimudin, A. (2013). Pengaruh Orientasi Wirausaha Terhadap Keunggulan Bersaing Berkelanjutan Dan Kinerja Pemasaran Usaha Kecil Sektor Perdagangan (Consumer Goods) Di Kota Surabaya. Sustainable Competitive Advantage (SCA), 3(1).

Alimudin, A., \& Sasono, A. D. (2015). PENINGKATAN DAYA SAING PRODUK KONVEKSI USAHA KECIL BERBASIS IPTEK DI DESA TRI TUNGGAL KECAMATAN BABAT LAMONGAN. Seminar Nasional Teknologi Terapan SV UGM.

Arifin, H. (2004). Cara memahami kerentanan perempuan pengusaha kecil. a way to understand the vulnerability of women-entrepreneurs). Analisis Sosial, 9(2), 157-170.

Dahlan, M. S. (2011). Statistik untuk kedokteran dan kesehatan. Salemba.

Darwin. (1998). Strategi Pemberdayaan Tenaga Kerja: Kasus Wanita Pedagang Kecil. Jakarta: PEP-LIPI.

DISKOP UKM JATIM. (2017). JUMLAH UMKM DI PROVINSI JAWA TIMUR MENURUT SEKTOR DAN KABUPATEN/KOTANo Title. Retrieved from http://diskopukm.jatimprov.go.id/view-media.php?pages=content\&id=57\&bidang=5

Endang S. (1999). Pengembangan Usaha Wanita Pedagang Kecil. Jakarta: PEP-LIPI.

Handayani, C. M. S., \& Wibowo, T. S. (2016). FAKTOR-FAKTOR YANG MEMPENGARUHI PENDAPATAN PEDAGANG KAKI LIMA STUDI KASUS PKL DI SURABAYA.

Majalah Ekonomi, 21(2), 286-294. Retrieved from

http://jurnal.unipasby.ac.id/index.php/majalah_ekonomi/article/view/418

Ilo, K. (2015). Tren Tenaga Kerja dan Sosial di Indonesia 2014 - 2015 Memperkuat daya saing dan produktivitas.

Jati, W. (2012). Analisis Motivasi Wirausaha Perempuan (Wirausahawati) di Kota MalangNo 
Title. Jurnal Humanity, 4(2).

Jatim, B. (2014). KEADAAN K ETENAGAKERJAAN FEBRUARI 2014. Retrieved from https://jatim.bps.go.id/4dm!n/brs_ind/brsInd-20141201095536.pdf

Mikkelsen, B. (2011). Metode penelitian partisipatoris dan upaya pemberdayaan: Panduan bagi praktisi lapangan. Yayasan Pustaka Obor Indonesia.

Prasetya, M. A., \& Fauziah, L. (2017). Dampak Sosial Ekonomi Relokasi Pedagang Kaki Lima di Kecamatan Buduran Kabupaten Sidoarjo. JKMP (Jurnal Kebijakan Dan Manajemen Publik), 4(2), 135-150.

Satrya, D. G. (2009). Wisata Kuliner Sebagai Penyelamat PKL di Kota Surabaya. Neo-Bis, 3(1). Retrieved from http://journal.trunojoyo.ac.id/neo-bis/article/view/578

Sri Lestari Harsosumarto. (2017). KOPERASI DAN PEMBERDAYAAN PEREMPUAN. INFOKOP, 15(1), 1-13. Retrieved from http://csmes.smecda.com/index.php/infokop/article/view/112

Statistik, B. P. (2016). Profil Kemiskinan Di Indonesia September 2016. Retrieved from https://www.bps.go.id/Brs/view/id/1378

Sumantri, B., Fariyanti, A., \& Winandi, R. (2013). Faktor-faktor yang Berpengaruh terhadap Kinerja Usaha Wirausaha Wanita: Suatu Studi pada Industri Pangan Rumahan di Bogor. Manajemen Teknologi, 12(3), 252-277. Retrieved from http://digilib.mercubuana.ac.id/manager/t!@file_artikel_abstrak/Isi_Artikel_299571919353. pdf

Suryani, H., \& Faizah, S. I. (2015). Peran Masjid Sebagai Roda Penggerak Perekonomian Masyarakat (Penelitian Deskriptif Pada PKL di Kawasan Masjid Al-Akbar Surabaya). Ekonomi Syariah Teori Dan Terapan, 2(5). https://doi.org/http://dx.doi.org/10.20473/vol2iss20155pp\%25p

Syaifudin, A. (2017). The Impact of Creativity and Innovation on Increasing Micro Enterprise Income PKL Gading Fajar Sidoarjo. IJEBD (International Journal Of Entrepreneurship And Business Development), 1(1).

Wahab, R. (2014). Metodologi penelitian kualitatif.

Wijaya, A. (1999). Perekonomian Indonesia Selama Krisis : Kenyataan dan Ramalan. In seminar refleksi 1998 dan prediksi 1999: antara harapan dan Kenyataan. Jakarta: IPSK-LIPI.

Wispandono, M. (2011). Upaya Mengurangi Penggangguran Melalui Peningkatan Wisata Kuliner (Studi Pada Pedagang Kaki Lima di Surabaya. Retrieved from http://www.journal.unipdu.ac.id/index.php/seminas/article/view/28

Zhou, Kevin Zheng, Chi Kin Yim, and D. K. T. (2005). The Efeect of strategic Orientations on Technology-and Market-Based Breakthrough Innova tions. Journal of Marketing, 69(April), 42-60. 